\title{
PERAN GALERI INVESTASI SYARIAH BURSA EFEK INDONESIA (GIS BEI) IAIN BENGKULU DALAM MENINGKATKAN LITERASI PASAR MODAL (Studi Kasus Masyarakat Sumur Dewa Air Sebakul)
}

\author{
Lucy Auditya \\ IAIN Bengkulu, Indonesia \\ E-mail: luckyaudityabkl@gmail.com
}

\begin{abstract}
The purpose of this study is to find out how the role of the IAIN Bengkulu Indonesia Stock Exchange Sharia Investment Gallery (GIS BEI) in increasing capital market literacy in the community so as to encourage an increase in fraudulent investment fraud. This research uses descriptive qualitative method. The data used are primary data and secondary data. Data collection techniques used were interviews, observation, and documentation in accordance with the problem under study, as well as data analysis techniques using the Miles and Huberman models. The results of this study reveal that the IDX Investment Gallery 3 in 1 concept which is a collaboration between the IDX, Universities and Securities Companies is expected to not only introduce the Capital Market in terms of theory but also practice. The existence of the IDX Investment Gallery is expected to provide mutual benefits for all parties so that the dissemination of capital market information is right on target and can provide optimal benefits for students, economic practitioners, investors, capital market observers and the general public in the area and its surroundings both for the purposes of socialization and education / capital market education as well as for economic or alternative investment interests to prevent fraudulent investment fraud.
\end{abstract}

Keyword: Financial Literacy, Capital Markets

Abstrak : Tujuan dari penelitian ini untuk mengetahui bagaimana peran Galeri Investasi Syariah Bursa Efek Indonesia (GIS BEI) IAIN Bengkulu dalam meningkatkan literasi Pasar Modal pada Masyarakat sehingga mendorong pengurangan penipuan investasi bodong. Penelitian ini menggunakan metode kualitatif deskriptif. Data yang digunakan adalah data primer dan data sekunder. Teknik pengumpulan data yang digunakan adalah wawancara, observasi, dan dokumentasi sesuai dengan masalah yang diteliti, serta teknik analisis data menggunakan model Miles dan Huberman. Hasil penelitian ini mengungkapkan bahwa Galeri Investasi BEI berkonsep 3 in 1 yang merupakan kerjasama antara BEI, Perguruan Tinggi dan Perusahaan Sekuritas diharapkan tidak hanya memperkenalkan Pasar Modal dari sisi teori saja akan tetapi juga prakteknya. Keberadaan Galeri Investasi BEI diharapkan dapat saling memberikan manfaat bagi semua pihak sehingga penyebaran informasi pasar modal tepat sasaran serta dapat memberikan manfaat yang optimal bagi mahasiswa, praktisi ekonomi, investor, pengamat pasar modal maupun masyarakat umum di daerah dan sekitarnya baik untuk kepentingan sosialisasi dan pendidikan/edukasi pasar modal maupun untuk kepentingan ekonomis atau alternatif investasi agar tidak terjadinya penipuan investasi bodong.

Kata Kunci: Literasi Keuangan, Pasar Modal

\section{A. PENDAHULUAN}

Pasar modal memiliki peran penting bagi perekonomian Indonesia karena pasar modal menjalankan dua fungsi yaitu 1) sebagai sarana pendanaan usaha atau sarana perusahaan untuk mendapatkan dana dari investor serta 2) sebagai sarana bagi masyarakat untuk berinvestasi pada instrumen keuangan. Pasar modal (capital market) adalah pasar tempat diperjualbelikanya semua instrumen jangka panjang (jangka waktu lebih dari 1 tahun), baik surat utang (obligasi), ekuiti (saham), reksa dana, instrumen derivatif maupun instrumen lainnya. Pasar modal merupakan sarana pendanaan bagi perusahaan maupun institusi lain (misalnya pemerintah), dan sebagai sarana bagi kegiatan berinvestasi. Dengan demikian, pasar modal memfasilitasi 
berbagai sarana dan prasarana kegiatan jual beli dan kegiatan terkait lainnya.

Undang-Undang Pasar Modal No.

8 tahun 1995 tentang Pasar Modal mendefinisikan pasar modal sebagai "kegiatan yang bersangkutan dengan Penawaran Umum dan perdagangan Efek, Perusahaan Publik yang berkaitan dengan Efek yang diterbitkannya, serta lembaga dan profesi yang berkaitan dengan Efek". Pasar Modal memiliki peran penting bagi perekonomian suatu negara karena pasar modal menjalankan dua fungsi, yaitu pertama sebagai sarana bagi pendanaan usaha atau sebagai sarana bagi perusahaan untuk mendapatkan dana dari masyarakat pemodal (investor). Dana yang diperoleh dari pasar modal dapat digunakan untuk pengembangan usaha, ekspansi, penambahan modal kerja dan lain-lain, kedua pasar modal menjadi sarana bagi masyarakat untuk berinvestasi pada instrument keuangan seperti saham, obligasi, reksa dana, dan lain-lain. Dengan demikian, masyarakat dapat menempatkan dana yang dimilikinya sesuai dengan karakteristik keuntungan dan risiko masing-masing instrument. ${ }^{1}$

Tahun 2017, pasar modal Indonesia mencatat kemajuan berarti

${ }^{1}$ http://www.idx.co.id/investor/pengantarpasar-modal/diaksespada 30 agustus 2018, pukul $14.00 \mathrm{wib}$ dari segi jumlah perusahaan tercatat, penambahan jumlah investor yang aktif, serta penguatan ketahanan pasar. Kerjasama yang baik antara Otoritas Jasa Keuangan (OJK), Bursa Efek Indonesia (BEI) beserta seluruh komponen anggota bursa yang terlibat di kegiatan pasar modal sangat membantu Percepatan pertumbuhan Pasar Modal di Indonesia. Percepatan tersebut disalurkan melalui berbagai langkah inovasi BEI, termasuk pengembangan Kantor Perwakilan BEI di kota-kota besar, pembukaan Galeri Investasi BEI di ratusan perguruan tinggi, pasar tradisional, serta pengenalan Yuk Nabung Saham hingga ke desa-desa di berbagai pelosok Nusantara. Bursa Efek Indonesia akan terus mendorong pertumbuhan Pasar Modal Indonesia dengan tata kelola yang baik, personil yang berkompetensi tinggi serta dukungan infrastruktur kelas dunia.

BEI mengerahkan segala daya dan serangkaian inisiatif untuk meningkatkan literasi pasar modal, antara lain dengan terus menggaungkan kampanye \#YukNabungSaham, optimasi fungsi pengembangan wilayah dan jangkauan BEI yang hingga akhir tahun 2017 telah mencakup 324 galeri investasi, 29 kantor perwakilan, dan 6 pusat informasi Go Public. Peresmian galeri investasi ini selaras dengan 
komitmen BEI dalam mempermudah masyarakat mendapatkan informasi terkait dengan pasar modal.

\section{Galeri Investasi Bursa Efek} Indonesia (BEI) adalah sarana untuk memperkenalkan Pasar Modal sejak dini kepada dunia akademisi. Galeri Investasi ini adalah salah satu langkah BEI memperluas inklusivitas Pasar Modal Indonesia. Galeri Investasi BEI berkonsep 3 in 1 ini merupakan kerjasama antara BEI, Perguruan Tinggi dan Perusahaan Sekuritas sebagai anggota bursa. Kerjasama tiga pihak ini diharapkan tidak hanya memperkenalkan Pasar Modal dari sisi teori saja akan tetapi juga prakteknya. .

Galeri Investasi BEI menyediakan semua publikasi dan bahan cetakan mengenai pasar modal yang diterbitkan oleh Bursa Efek Indonesia termasuk peraturan dan Undang-Undang Pasar Modal. Informasi dan data yang ada di Galeri Investasi BEI dapat digunakan oleh civitas akademika untuk tujuan akademik dan penelitian, maupun sebagai referensi dalam pengambilan keputusan saat melakukan transaksi jual dan beli Efek, tapi bukan untuk tujuan komersial dalam hal transaksi jual dan beli saham.

Keberadaan Galeri Investasi BEI diharapkan dapat saling memberikan manfaat bagi semua pihak sehingga penyebaran informasi pasar modal tepat sasaran serta dapat memberikan manfaat yang optimal bagi mahasiswa, praktisi ekonomi, investor, pengamat pasar modal maupun masyarakat umum dan menambah literasi keuangan di daerah dan sekitarnya baik untuk kepentingan sosialisasi dan pendidikan/edukasi pasar modal secara berkesinambungan maupun untuk kepentingan ekonomis atau alternatif investasi. ${ }^{2}$

Sejak tahun 2000, PT Bursa Efek Indonesia (BEI) telah bekerjasama dengan Perguruan Tinggi dan Perusahaan Sekuritas untuk menempatkan Galeri Investasi di berbagai kampus Perguruan Tinggi, sebagai sarana untuk memperkenalkan Pasar Modal sejak dini kepada dunia akademisi. Namun, Galeri Investasi tidak hanya memberikan pengunjung sebuah pemahaman pasar modal secara teori, melainkan juga memberikan kesempatan untuk melakukan simulasi serta bertransaksi secara langsung dan real time.

Di dalam Galeri Invetasi, tersedia berbagai informasi mengenai pasar modal termasuk ketentuan pasar modal. Meskipun awalnya pelaksanaan Galeri Investasi tersebut hanya difokuskan untuk kalangan mahasiswa saja. Namun, belakangan ini galeri investasi telah

${ }^{2}$ http://www.idx.co.id/produk/galeriinvestasi-bei/ (diakses tanggal : 30 Agustus 2018 Pukul 15:41 
didorong untuk lebih terbuka dan melakukan sosialisasi pasar modal terhadap masyarakat lain di sekitar kampus yang merupakan investor potensial. Program tersebut dinamakan Galeri Investasi Mobile (GIM) dan telah berjalan sejak $2016 .^{3}$

\section{B. LANDASAN TEORI}

\section{Literasi Keuangan}

Literasi keuangan (financial literacy) merupakan pemahaman terhadap keuangan, menurut buku pedoman strategi nasional literasi keuangan Indonesia, yang dimaksud dengan literasi keuangan adalah rangkaian proses atau aktivitas untuk meningkatkan pengetahuan (knowledge), keyakinan (confidence), dan keterampilan (skill) konsumen dan masyarakat luas sehingga mereka mampu mengelola keuangan yang lebih baik.

Literasi keuangan tidak akan sampai pada masyarakat bila tidak ada suatu upaya yang dilakukan oleh pemerintah maupun lembaga dalam mensosialisasikan tentang literasi keuangan tersebut. Sosialisasi mengenai literasi keuangan di Indonesia di lakukan oleh Galeri Investasi bekerjasama dengan Bursa

${ }^{3}$ Indonesia Bond Market Directory 2016-
Efek Indonesia dan Otoritas Jasa Keuangan sebagai sebuah lembaga pengawas industri jasa keuangan di Indonesia. Diharapkan dengan melakukan literasi keuangan tentang pasar modal akan meminimalisir masyarakat untuk tertipu dengan adanya investasi bodong yang sedang marak terjadi di kalangan masyarakat.

Literasi keuangan sangat penting untuk seseorang dalam membuat keputusan terutama yang berkaitan dengan aktivitas sehari-hari seperti dalam mengambil keputusan untuk menabung (saving) atau investasi (Investment) untuk mencapai tujuan yang sudah ditentukan sebelumnya. Literasi keuangan selain bermanfaat bagi individunya sendiri juga bermanfaat untuk keberlangsungan sistem perekonomian suatu Negara.

Literasi keuangan merupakan pengetahuan, keterampilan, dan keyakinan yang mempengaruhi sikap dan perilaku untuk meningkatkan kualitas pengambilan keputusan dan pengelolaan keuangan dalam rangka mencapai kesejahteraan.

Pelaksanaan Edukasi dalam rangka meningkatkan keuangan masyarakat sangat diperlukan karena berdasarkan survei yang dilakukan oleh OJK pada 2013, bahwa tingkat 
literasi keuangan penduduk Indonesia dibagi menjadi empat bagian, yakni:

a. Well literate $(21,84 \%)$, yakni memiliki pengetahuan dan keyakinan tentang lembaga jasa keuangan serta produk jasa keuangan, termasuk fitur, manfaat dan risiko, hak dan kewajiban terkait produk dan jasa keuangan, serta memiliki keterampilan dalam menggunakan produk dan jasa keuangan.

b. Sufficient literate $(75,69 \%)$, memiliki pengetahuan dan keyakinan tentang lembaga jasa keuangan serta produk dan jasa keuangan, termasuk fitur, manfaat dan risiko, hak dan kewajiban terkait produk dan jasa keuangan.

c. Less literate (2,06\%), hanya memiliki pengetahuan tentang lembaga jasa keuangan, produk dan jasa keuangan.

d. Not literate $(0,41 \%)$, tidak memiliki pengetahuan dan keyakinan terhadap lembaga jasa keuangan serta produk dan jasa keuangan, serta tidak memiliki keterampilan dalam menggunakan produk dan jasa keuangan.

Literasi Keuangan memiliki tujuan jangka panjang bagi seluruh golongan masyarakat, yaitu: a. Meningkatkan literasi seseorang yang sebelumnya less literate atau not literate menjadi well literate;

b. Meningkatkan jumlah pengguna produk dan layanan jasa keuangan.

Agar masyarakat luas dapat menentukan produk dan layanan jasa keuangan yang sesuai dengan kebutuhan, masyarakat harus memahami dengan benar manfaat dan risiko, mengetahui hak dan kewajiban serta meyakini bahwa produk dan layanan jasa keuangan yang dipilih dapat meningkatkan kesejahteraan masyarakat.

a. Bagi masyarakat, Literasi Keuangan memberikan manfaat yang besar, seperti:

b. Mampu memilih dan memanfaatkan produk dan layanan jasa keuangan yang sesuai kebutuhan; memiliki kemampuan dalam melakukan perencanaan keuangan dengan lebih baik;

c. Terhindar dari aktivitas investasi pada instrumen keuangan yang tidak jelas;

Mendapatkan pemahaman mengenai manfaat dan risiko produk dan layanan jasa keuangan. Literasi Keuangan juga memberikan manfaat yang besar bagi sektor jasa keuangan. Lembaga keuangan dan masyarakat saling membutuhkan satu sama lain 
sehingga semakin tinggi tingkat Literasi Keuangan masyarakat, maka semakin banyak masyarakat yang akan memanfaatkan produk dan layanan jasa keuangan. ${ }^{4}$

Menurut Otoritas Jasa Keuangan (2014), tingkatan literasi keuangan seseorang dibedakan menjadi empat jenis tingkat, yaitu:

a. Well Literate. Pada tahap ini, seseorang memiliki pengetahuan dan keyakinan tentang lembaga jasa keuangan serta produk dan jasa keuangan, termasuk fitur, manfaat dan risiko, hak dan kewajiban terkait produk dan jasa keuangan, serta memiliki keterampilan dalam menggunakan produk dan jasa keuangan.

b. Suff Literate. Pada tahap ini, seseorang memiliki pengetahuan dan keyakinan tentang lembaga jasa keuangan serta produk dan jasa keuangan, termasuk fitur, manfaat dan risiko, hak dan kewajiban terkait produk dan jasa keuangan.

c. Less Literate. Pada tahap ini, seseorang hanya memiliki pengetahuan tentang lembaga jasa keuangan, produk dan jasa keuangan.

${ }^{4}$ https://www.ojk.go.id/id/kanal/edukasidan-perlindungan-konsumen/Pages/LiterasiKeuangan.aspx (diakses tanggal : 30 Agustus 2018 Pukul 16:05) d. Not Literate. Pada tahap ini, seseorang tidak memiliki pengetahuan dan keyakinan tentang lembaga jasa keuangan serta produk dan jasa keuangan, serta tidak memiliki keterampilan dalam menggunakan produk dan jasa keuangan.

Menurut Chen dan Volpe, literasi keuangan terbagi menjadi empat aspek, yaitu sebagai berikut:

a. Pemahaman beberapa hal yang berkaitan dengan pengetahuan dasar tentang keuangan pribadi.

b. Savings and borrowing (tabungan dan pinjaman), bagian ini meliputi pengetahuan yang berkaitan dengan tabungan dan pinjaman seperti penggunaan kartu kredit.

c. Insurance (asuransi), bagian ini meliputi pengetahuan dasar asuransi, dan produk-produk asuransi seperti asuransi jiwa dan asuransi kendaraan bermotor.

d. Investment (investasi), bagian ini meliputi pengetahuan tentang suku bunga pasar, reksadana, dan risiko investasi.

Literasi keuangan dicerminkan oleh pengetahuan dan kemampuan seseorang secara kognitif mengenai keuangan. Menurut Remund (2010:45), terdapat empat hal yang paling umum dalam literasi keuangan, 
yaitu pengetahuan dan kemampuan mengenai penganggaran, tabungan, pinjaman dan investasi. Variabel Literasi keuangan secara lebih luas mengukur kemampuan seseorang berkaitan dengan pemahaman mengenai nilai tukar uang, fitur jasa layanan keuangan, pencatatan keuangan, sikap dalam mengeluarkan keuangan, terdapat beberapa hal dalam pengukuran literasi keuangan, yaitu:

a. Menyusun/merencanakan anggaran penghasilan yang akan diterima.

b. Menyusun/merencanakan anggaran biaya yang akan dikeluarkan.

c. Kepatuhan terhadap rencana anggaran pengeluaran.

d. Pemahaman atas nilai riil uang.

e. Pemahaman nilai nominal uang.

f. Pemahaman tentang inflasi.

Menurut Australian Securities \& Investment Commission, untuk mengetahui seberapa besar tingkat literasi keuangan seseorang dapat digunakan tolok ukur pengetahuan sebagai berikut:

a. Pengetahuan seseorang atas nilai suatu barang dan skala prioritas dalam hidupnya.

b. Penganggaran, tabungan dan bagaimana mengelola uang.

c. Pengelolaan kredit.

d. Pentingnya asuransi dan melindungi terhadap resiko. e. Dasar-dasar investasi.

f. Perencanaan pensiun.

g. Pemanfaatan dari belanja dan membandingkan produk dimana harus pergi mencari saran dan informasi bimbingan, dan dukungan tambahan.

h. Bagaimana mengenali potensi konflik atas kegunaan (prioritasi).

Otoritas Jasa Keuangan (OJK) mengajak masyarakat Provinsi Bengkulu lebih memahami literasi keuangan sebelum menentukan sektor finansial yang dibutuhkan. Kepala Perwakilan OJK Provinsi Bengkulu Yan Syafri mengatakan, pemahaman tentang literasi keuangan sangat penting untuk mengembangkan kemampuan masyarakat menilai produk jasa keuangan. Dengan lengkapnya literasi tentang keuangan, tambah Yan, masyarakat menjadi lebih cermat dan tidak salah memilih model jasa yang disediakan lembaga keuangan.

Berdasarkan survei nasional literasi keuangan yang dilakukan OJK pada 2016, dari 67,86 masyarakat yang menggunakan produk dan layanan keuangan, hanya 29,66 persen penduduk memiliki pengetahuan, ketrampilan, kepercayaan, sikap dan perilaku yang memadai dalam menggunakan produk dan layanan 
keuangan. Untuk mewujudkan masyarakat yang memahami literasi, OJK mengharapkan dukungan pemangku kepentingan, khususnya industri jasa keuangan untuk bersamasama melakukan kegiatan edukasi keuangan dan menyediakan produk dan layanan keuangan yang mudah dan murah.

\section{Pasar Modal}

Pasar Modal Secara etimologis, untuk istilah pasar digunakan kata bursa, exchange dan market. Adapun untuk istilah modal sering digunakan kata efek, securities dan stock. ${ }^{5}$ Dalam arti sempit pengertian pasar merupakan tempat para penjual dan pembeli bertemu untuk melakukan transaksi. Artinya pembeli dan penjual langsung bertemu untuk melakukan transaksi dalam suatu lokasi tertentu. Lokasi atau tempat pertemuan tersebut disebut pasar. Namun, dalam arti luas pengertian pasar merupakan tempat melakukan transaksi antara penjual dan pembeli, di mana pembeli dan penjual tidak harus bertemu daam suatu tempat atau bertemu langsung, tetapi dapat dilakukan melalui sarana informasi yang ada seperti sarana

${ }^{5}$ Juhaya S. Pradja, Lembaga keuangan syariah suatu kajian teoritis praktis (Bandung: CV Pustaka Setia, 2012) hlm. 343 informatika. ${ }^{6}$ Pengertian modal secara umum merupakan suatu tempat bertemunya para penjual dan pembeli untuk melakukan transaksi dalam rangka memperoleh modal.

Definisi pasar modal menurut Kamus Pasar Modal dan Modal adalah pasar konkret atau abstrak yang mempertemukan pihak yang menawarkan dan memerlukan dana jangka panjang, yaitu jangka satu tahun ke atas. Umumnya yang termasuk pihak penawar adalah perusahaan asuransi, dana pensiun, bank-bank tabungan sedangkan yang termasuk peminat adalah perusahaan, pemerintah, dan masyarakat umum. Pasar modal berbeda dengan pasar uang (money market). Pasar uang berkaitan dengan instrumen keuangan jangka pendek (jatuh tempo kurang dari 1 tahun) dan merupakan pasar yang abstrak. Istrumen pasar uang biasanya terdiri dari berbagai jenis surat berharga jangka pendek seperti sertifikat deposito, commercial paper, Sertifikat Bank Indonesia (SBI), dan Surat Berharga Pasar Uang (SBPU).

Penjual dalam pasar modal merupakan perusahaan yang membutuhkan modal (emiten), sehingga mereka berusaha untuk

\footnotetext{
${ }^{6}$ Kasmir, Bank dan Lembaga Keuangan Lainnya, (Jakarta: PT.Raja Grafindo, 2012) hlm 207
} 
menjual efek-efek di pasar modal. Sedangkan pembeli (investor) adalah pihak yang ingin membeli modal diperusahaan yang menurut mereka menguntungkan. ${ }^{7}$ Menurut UndangUndang No. 8 tahun 1995 tentang Pasar Modal, yang dimaksud dengan pasar modal adalah kegiatan yang berkaitan dengan penawaran umum dan perdagangan efek, Perusahaan publik yang berkaitan dengan efek yang diterbitkannya serta lembaga dan profesi yang berkaitan dengan efek. ${ }^{8}$

Pasar modal menjalankan fungsi ekonomi, yaitu menyediakan fasilitas untuk memindahkan dana dari pihak yang memiliki dana berlebih kepada pihak yang memerlukan dana, sedangkan fungsi keuangan dari pasar modal yaitu menyediakan sarana bagi pihak yang memerlukan dana dan pihak yang kelebihan dana tanpa harus terlibat langsung dalam kepemilikan aktual riil yang diperlukan untuk investasi.

Peran pasar modal bagi individu, perusahaan, maupun perekonomian, maka suatu negara harus memiliki pasar modal yang baik (sehat). Pasar modal akan berjalan dengan baik jika informasi yang diperlukan oleh pihak

\footnotetext{
${ }^{7}$ Kasmir, Bank dan Lembaga... hlm. 207

${ }^{8}$ Juhaya S. Pradja, Lembaga keuangan syariah... hlm. 344
}

yang terlibat didalamnya dapat diperoleh dengan cepat, tepat, akurat, kontinu, dan efisien. Pasar modal yang dapat berfungsi dengan baik (sehat) akan dapat meningkatkan kinerja ekonomi melalui peningkatan pendapatan nasional, terciptanya kesempatan kerja, dan meratanya hasil-hasil pembangunan yang dirasakan oleh masyarakat.

Dalam sejarah Pasar Modal Indonesia, kegiatan jual beli saham dan obligasi dimulai pada abad ke-19. Menurut buku Effectengids yang dikeluarkan oleh Verreninging voor den Effectenhandel pada tahun 1939, jual beli efek telah berlangsung sejak 1880. Pada tanggal Desember 1912 , Amserdamse Effectenbeurs mendirikan cabang bursa efek di Batavia. Di tingkat Asia, bursa Batavia tersebut merupakan yang tertua keempat setelah Bombay, Hongkong, dan Tokyo. Aktivitas yang sekarang diidentikkan sebagai aktivitas pasar midal sudah sejak tahun 1912 di Jakarta. Aktivitas ini pada waktu itu dilakukan oleh orang-orang Belanda di Batavia yang dikenal sebagai Jakarta saat ini. Sekitar awal abad ke-19 pemerintah kolonial Belanda mulai membangun perkebunan secara besar-besaran di Indonesia. Sebagai salah satu sumber 
dana adalah dari para penabung yang telah dikerahkan sebaik-baiknya. Para penabung tersebut terdiri dari orangorang Belanda dan Eropa lainnya yang penghasilannya sangat jauh lebih tinggi dari penghasilan penduduk pribumi. Atas dasar itulah maka pemerintahan kolonial waktu itu mendirikan pasar midal. Setelah mengadakan persiapan akhirnya berdiri secara resmi pasar midal di Indonesia yang terletak di Batavia (Jakarta) pada tanggal 14 Desember 1912 dan bernama Verreninging voor den Effectenhandel (bursa efek) dan langsung memulai perdagangan. Efek yang dperdagangkan pada saat itu adalah saham dan obligasi perusahaan milik perusahaan Belanda serta obligasi pemerintah Hindia Belada. Bursa Batabia dihentikan pada perang dunia yang pertama dan dibuka kembali pada tahun 1925 dan menambah jangkauan aktivitasnya dengan membuka bursa paralel di Surabaya dan Semarang. Adapun manfaat pasar modal adalah :

a. Bagi Emiten

Bagi emiten, pasar modal memiliki beberapa manfaat, antara lain:

1) jumlah dana yang dapat dihimpun berjumlah besar
2) dana tersebut dapat diterima sekaligus pada saat pasar perdana selesai

3) tidak ada convenantsehingga manajemen dapat lebih bebas dalam pengelolaan dana/perusahaan

4) solvabilitas perusahaan tinggi sehingga memperbaiki citra perusahaan

5) ketergantungan emiten terhadap bank menjadi lebih kecil

b. Bagi Investor

Sementara, bagi investor, pasar modal memiliki beberapa manfaat, antara lain:

1) nilai investasi perkembang mengikuti pertumbuhan ekonomi. Peningkatan tersebut tercermin pada meningkatnya harga saham yang mencapai kapital gain

2) memperoleh dividen bagi mereka yang memiliki/memegang saham dan bunga yang mengambang bagi pemenang obligasi.

3) dapat sekaligus melakukan investasi dalam

beberapa instrumen yang mengurangi risiko

Pasar modal dibedakan menjadi 2 yaitu pasar perdana dan pasar sekunder : 
a. Pasar Perdana ( Primary Market)

Pasar Perdana adalah penawaran saham pertama kali dari emiten kepada para pemodal selama waktu yang ditetapkan oleh pihak penerbit (issuer) sebelum saham tersebut belum diperdagangkan di pasar sekunder. Biasanya dalam jangka waktu sekurang-kurangnya 6 hari kerja. Harga saham di pasar perdana ditetukan oleh penjamin emisi dan perusahaan yang go public berdasarkan analisis fundamental perusahaan yang bersangkutan.

Dalam pasar perdana, perusahaan akan memperoleh dana yang diperlukan. Perusahaan dapat menggunakan dana hasil emisi untuk mengembangkan dan memperluas barang modal untuk memproduksi barang dan jasa. Selain itu dapat juga digunakan untuk melunasi hutang dan memperbaiki struktur pemodalan usaha. Harga saham pasar perdana tetap, pihak yang berwenang adalah penjamin emisi dan pialang, tidak dikenakan komisi dengan pemesanan yang dilakukan melalui agen penjualan.

b. Pasar Sekunder(Secondary Market)

Pasar sekunder adalah tempat terjadinya transaksi jual-beli saham diantara investor setelah melewati masa penawaran saham di pasar perdana, dalam waktu selambatlambatnya 90 hari setelah ijin emisi diberikan maka efek tersebut harus dicatatkan di bursa.

Dengan adanya pasar sekunder para investor dapat membeli dan menjual efek setiap saat. Sedangkan manfaat bagi perusahaan, pasar sekunder berguna sebagai tempat untuk menghimpun investor lembaga dan perseorangan.

Harga saham pasar sekunder berfluktuasi sesuai dengan ekspetasi pasar, pihak yang berwenang adalah pialang, adanya beban komisi untuk penjualan dan pembelian, pemesanannya dilakukan melalui anggota bursa, jangka waktunya tidak terbatas.

Tempat terjadinya pasar sekunder di dua tempat, yaitu :

1) Bursa regular; Bursa reguler adalah bursa efek resmi seperti Bursa Efek Jakarta (BEJ), dan Bursa Efek Surabaya (BES)

2) Bursa parallel; Bursa paralel atau over the counter adalah suatu sistem perdagangan efek yang terorganisir di luar bursa efek resmi, dengan bentuk pasar sekunder yang diatur dan diselenggarakan oleh 
Perserikatan Perdagangan Uang

dan Efek-efek (PPUE), diawasi

dan dibina oleh Bapepam. Over

the counter karena pertemuan

antara penjual dan pembeli tidak

dilakukan di suatu tempat

tertentu tetapi tersebar diantara

kantor para broker atau dealer.

Pasar Uang berbeda dengan

Pasar Modal yang tradingnya dilakukan melalui Bursa atau Stock Exchange. Pasar Uang sifatnya abstrak, tidak ada tempat khusus seperti halnya dengan Pasar Modal, transaksi pada Pasar Uang dilakukan secara OTC (Over The Counter Market) dilakukan oleh setiap peserta (partisipan) melalui Desk atau Dealing Room masing-masing peserta.

Alasan kenapa pasar uang dibutuhkan dalam sistem perekonomian adalah banyaknya perusahaan serta individu yang mengalami arus kas yang tidak sesuai antara inflows dan outflows.

Misalnya, perusahaan melakukan penagihan dari klien pada periode tertentu dan pada waktu yang lain ia harus mengeluarkan uang untuk menutupi biaya operasionalnya.

Untuk mengatasi masalah tersebut (perusahaan pada saat kasnya mengalami defisit), maka perusahaan tersebut sementara dapat memasuki pasar uang sebagai peminjam dengan mencari lembaga keuangan atau pihak lain yang memiliki surplus (kelebihan) dana. Selanjutnya, pada saat perusahaan tersebut mengalami surplus dana, maka perusahaan tersebut menjadi kreditor dalam pasar uang untuk memperoleh pendapatan daripada membiarkan dananya tak terpakai atau idle.

Kebutuhan akan adanya pasar uang dilatarbelakangi adanya kebutuhan untuk mendapatkan sejumlah dana dalam jangka pendek atau yang sifatnya harus segera dipenuhi. Dengan demikian pasar uang merupakan sarana alternatif, khususnya bagi lembagalembaga keuangan, perusahaanperusahaan non keuangan, dan peserta-peserta lainnya, baik dalam memenuhi kebutuhan dana jangka pendeknya maupun dalam rangka melakukan penempatan dana atas kelebihan likuiditasnya.

\section{METODE PENELITIAN}

Penelitian ini dilakukan di Galeri Investasi Syariah BEI IAIN Bengkulu dengan jenis penelitian lapangan (field research) yang bersifat deskriptif. ${ }^{9}$

${ }^{9}$ Juliansyah Noor, Metodologi Penelitian, (Jakarta: Kencana, 2011), hlm. 34 
Pendekatan penelitian ini adalah pendekatan kualitatif. Pendekatan kualitatif adalah suatu proses peneliti dan pemahaman yang berdasarkan pada metodelogi yang menyelidiki suatu fenomena sosial dan masalah manusia. Pada pendekatan ini, peneliti menekankan sifat realistis yang terbangun secara sosial hubungan erat antara peneliti dari subjek yang diteliti.

\section{HASIL DAN PEMBAHASAN}

Pasar modal (capital market) adalah pasar tempat diperjualbelikanya semua instrumen jangka panjang (jangka waktu lebih dari 1 tahun), baik surat utang (obligasi), ekuiti (saham), reksa dana, instrumen derivatif maupun instrumen lainnya. Pasar modal merupakan sarana pendanaan bagi perusahaan maupun institusi lain (misalnya pemerintah), dan sebagai sarana bagi kegiatan berinvestasi. Dengan demikian, pasar modal memfasilitasi berbagai sarana dan prasarana kegiatan jual beli dan kegiatan terkait lainnya.

Pasar Modal memiliki peran penting bagi perekonomian suatu negara karena pasar modal menjalankan dua fungsi, yaitu pertama sebagai sarana bagi pendanaan usaha atau sebagai sarana bagi perusahaan untuk mendapatkan dana dari masyarakat pemodal (investor). Dana yang diperoleh dari pasar modal dapat digunakan untuk pengembangan usaha, ekspansi, penambahan modal kerja dan lain-lain, kedua pasar modal menjadi sarana bagi masyarakat untuk berinvestasi pada instrument keuangan seperti saham, obligasi, reksa dana, dan lain-lain. Dengan demikian, masyarakat dapat menempatkan dana yang dimilikinya sesuai dengan karakteristik keuntungan dan risiko masing-masing instrument.

Keberadaan Galeri Investasi BEI diharapkan dapat saling memberikan manfaat bagi semua pihak sehingga penyebaran informasi pasar modal tepat sasaran serta dapat memberikan manfaat yang optimal bagi mahasiswa, praktisi ekonomi, investor, pengamat pasar modal maupun masyarakat umum dan menambah literasi keuangan di daerah dan sekitarnya baik untuk kepentingan sosialisasi dan pendidikan/edukasi pasar modal secara berkesinambungan maupun untuk kepentingan ekonomis atau alternatif investasi. Namun, Galeri Investasi tidak hanya memberikan pengunjung sebuah pemahaman pasar modal secara teori, melainkan juga memberikan kesempatan untuk melakukan simulasi serta bertransaksi secara langsung dan real time. Di dalam Galeri Invetasi, tersedia berbagai informasi mengenai pasar modal termasuk ketentuan pasar modal. Dan memberikan pengetahuan kepada 
masyarakat tentang invetasi yang aman dan bukan penipuan seperti investasi bodong.

\section{E. KESIMPULAN}

Peran GIS BEI IAIN Bengkulu dalam meningkatkan Literasi Pasar modal pada masyarakat adalah memberikan manfaat bagi semua pihak sehingga penyebaran informasi pasar modal tepat sasaran serta dapat memberikan manfaat yang optimal bagi mahasiswa, praktisi ekonomi, investor, pengamat pasar modal maupun masyarakat umum dan menambah literasi keuangan di daerah dan sekitarnya baik untuk kepentingan sosialisasi dan pendidikan/edukasi pasar modal secara berkesinambungan maupun untuk kepentingan ekonomis atau alternatif investasi. Namun, Galeri Investasi tidak hanya memberikan pengunjung sebuah pemahaman pasar modal secara teori, melainkan juga memberikan kesempatan untuk melakukan simulasi serta bertransaksi secara langsung dan real time. Di dalam
Galeri Invetasi, tersedia berbagai informasi mengenai pasar modal termasuk ketentuan pasar modal. Dan memberikan pengetahuan kepada masyarakat tentang invetasi yang aman dan bukan penipuan seperti investasi bodong.

\section{DAFTAR PUSTAKA}

Indonesia Bond Market Directory 206-2017

Kasmir, Bank dan Lembaga Keuangan Lainnya, (Jakarta: PT.Raja Grafindo, 2012)

Noor, Juliansyah, Metodologi Penelitian, (Jakarta: Kencana, 2011)

S. Pradja, Juhaya , Lembaga keuangan syariah suatu kajian teoritis praktis (Bandung: CV Pustaka Setia, 2012)

http://www.idx.co.id/investor/pengantarpasar-modal/diaksespada 30 agustus 2018, pukul 14.00 wib

http://www.idx.co.id/produk/galeriinvestasi-bei/ (diakses tanggal : 30 Agustus 2018 Pukul 15:41

https://www.ojk.go.id/id/kanal/ed ukasi-dan-perlindungan-

konsumen/Pages/Literasi-Keuangan.aspx (diakses tanggal : 30 Agustus 2018 Pukul 16:05) 